\title{
IS IS
}

Extended Abstract

\section{Experience and narrative in digital era: the 'binge-viewing' case.}

\section{Bernardo Barros Oliveira.}

${ }^{1}$ Universidade Federal Fluminense - UFF (Fluminense Federal University) - Niterói, Rio de Janeiro State, Brazil. Department of Philosophy - Campus Gragoatá -Rua Waldemar de Freitas Reis, Bloco O, sl. 310, São Domingos, Niterói, Brazil. Cep. 24210-201

E-Mails: bernardobcdeoliveira@yahoo.com.br

* Author to whom correspondence should be addressed; Tel.: 55021 35188040. Rua Cardoso Júnior, $\mathrm{n}^{\circ}$ 66/303, Laranjeiras, Rio de Janeiro, Brazil. Cep. 22245-000.

Accepted:

\section{Introduction}

This study proposes to analyze the phenomenon known as "Binge-watching" or "Bingeviewing", widely commented on in the press today ${ }^{i}$. This is the widespread habit of watching, without interruptions, numerous chapters or even entire seasons of television series through internet streaming. The theoretical background for this analysis is the relationship between the historical sense of the word experience and the practice of narrative, understood in the broader sense. This is based on Walter Benjamin's proposal to associate the notion of experience with that of narrative discourse, both focused on a radically historical sense. The displacements and historical revaluations of the three "communication forms" ("Formen der Mitteilung",ii), the oral narrative, the written novel and journalistic information, supply the conductive thread for Benjamin to weave a theory of different experience values. The retraction of the art of exchanging experiences in the capitalist and urban world, given concomitantly with the flourishing of the novel, in the 18th and 19th centuries, weakened the sense of experience privileged by Benjamin, centered on the concepts of transmission and collective and diachronic enrichment of stories. Life as an experience ("Erfahrung") is the transformation of the time lived as a whole, rich in meaning capable of being transmitted. Experience narrativization is the consequence and consummation of search for meaning for the time lived, through the organization of pure succession as a whole with a beginning, middle and end, in which the 
sequence of events suggests itself as a discursive intelligibility to be interpreted and appropriated by the listener, reader or spectator.

The experience value is diminished when what is at stake in a story is no more the condensation of experiential knowledge. In the case of the novel reading, at least to Benjamin, the experiential value is deprecated in favor of the solitary dive into the fictional character world of the psychologically shaped realistic novel. This value is even more parlous when the reader is shaped by journalistic information logic, anchored in a momentary reference to the most current and familiar as possible. Experience in the strong sense (Erfahrung), is, in the modern world, transmuted in "Erlebnis", a set of radically individual loosely connected memories and sensations.

This historic panel, painted by Benjamin in the 1930s, faced with current conditions, provides a basis for thinking about today's experience value. Is the Erlebnis concept valid to depict today's state of things? Isn't its molding after the 19th century bourgeois subject reader in need of review, using the same method employed by Benjamin? According to the indications inferred by Benjamin's theoretical practice, in the essay "The storyteller", as in other important 1930's writings, such as "The work of art at the time of its technical reproducibility" and "On some themes in Baudelaire", his method consisted in seeking, in artistic forms preferred during an epoch, strong evidence about the current state of experience. This elective affinity of an epoch with certain art forms is what Benjamin called "social meaning" ("gesellshaftliche Bedeutung") of an art. There is an intense adjustment between the epoch and the works of art when the receiver not only enjoys the products, but also feels himself able to criticize them, as was, according to the author, the case of the cinema to the 1930s public. It is believed that various contemporary narrative forms, such as "media novels", "fan fictions", and the once little valued TV series episodes, which have recently achieved high prestige, can be listed as forms elected by our time. Taking this later form and its reception as an object of analysis, what can we then understand about the current state of experience?

\section{Methods}

The method used is that inferred in the essay "The Storyteller", as well as "On some themes in Baudelaire" and "The work of art at the age of mechanical reproduction", to consider the artistic forms endowed with "social meaning" by an epoch, in relation to the experience concept and its transformations. The TV series, consumed in today's internet digital environment, in whole season packets and assisted in long sessions lasting sometimes whole weekends, is a phenomenon called "binge-watching" or "binge-viewing" by the press. Can this provide a valid work of art case with social signification? If so, what does it show regarding the experientiality in the contemporary world? Paul Ricoeur's theories are also used, in regard to the relationship between the narrative forms and the constitution of a "narrative identity"iii . These identities, always in the making and in no way endorsing the notion of a Cartesian substantial subject, may belong to a person, a group or a community. This notion of narrative identity can be put into a dialogue with the concept of experience in Benjamin, and added to the question regarding the supposed narrative identity mode in the case of "binge-watching".

\section{Results and Discussion}

The phenomenon analysis of television series reception in the digital environment, must take into account that this media is not simply a neutral vehicle, the bearer of a narrative material, but as a 
transforming element of this art form. The TV series and its reception is transformed by new media, and gains new social meaning. Contrary to the logic of attention fragmentation, which is dominant in the internet digital environment, the consumption of a chain of episodes, characterized as "compulsive" by the press, leads to a fictional submersion. Does this permit the supposition that the experience concept, in its link with narrative forms, in this case, is somehow renewed? The example of prolonged and personalized watching, partially stigmatized by the press as an addiction and compulsion ("Binge"), may additionally indicate a kind of experience nostalgia? The narrative structure, in general, is based on the concept of order and closing, producing interconnection between the events. Would this kind interconnection between the events be enhanced by the longer watching, compared to former reception through the TV channels, which had wide intervals between the episodes? Can the new attention type generated by the continual linking of episodes and the strong whole memory, along with the intensive knowledge process of the characters, their intentions and their dilemmas, represent an unexpected narrative discourse revaluation in an online environment whose dominant forces are frankly contrary to any process involving continuous use and exclusive attention?

\section{Conclusions}

Although the compulsive episode consumption leads to a thread that promotes the partial rehabilitation of an intensive use of narrative space, atypical within our epoch scenario in which dispersion and distraction encouragement is unequivocal, it is nonetheless, simply consumption. The phenomenon stigmatization by the press demonstrates only that even this consumption form is less dispersive than the main online trending behavior. The phenomenon is indeed a little auspicious, because it indicates at least a tenuous ongoing need for narratives with a logic that is proper for this type of discourse, so strange to the fragmentary nature of this digital media. But the serie's weak structure toward achieving an end, an almost a never-ending production of new seasons, guided only by popularity ratings, provide little or no support to narrative identity formation, contributing to leaving free space for subject formatting through consumption habits and its stereotypes.

\section{Acknowledgments}

\section{References and Notes}

Benjamin, Walter. "Der Erzähler. Betrachtungen zum Werk Nikolai Lesskows”. Gesammelte Schriften. Bd. II-2. Frankfurt: Suhrkamp, 1996.

"Das Kunstwerk im Zeitalter seiner technischen Reproduzierbarkeit". Gesammelte Schriften. Bd. I-2. Frankfurt: Suhrkamp, 1996.

Frankfurt: Suhrkamp, 1996.

"Über einige Motive bei Baudelaire". Gesammelte Schriften. Bd. I-2.

Brooks, Peter. Reading for the plot. Design and intention in narrative. Cambridge: Havard University Press, sd.

Kermode, Frank. The sense of na ending. Studies in the theory of fiction. Oxford: University Press, 2000.

Ricoeur, Paul. Temps et Rècit III. Le temps raconté. Paris: Ed. Du Seuil, 1985. 
' See, among many others, John Jurgensen's article at Wall Street Journal: "Binge Viewing: TV's Lost Weekends". http://www.wsj.com/articles/SB10001424052702303740704577521300806686174

ii Benjamin, Walter. "Der Erzähler. Betrachtungen zum Werk Nikolai Lesskows". GS II-2, p. 443.

iii Ricoeur, Paul. Temps et Rècit III. Le temps raconté. Paris: Ed. Du Seuil, 1985. 